\title{
O poder pastoral como diaconia caritatis: um olhar histórico-teológico do diaconado em sua tessitura no tempo
}

\author{
The pastoral reach as diaconia caritatis: \\ A historical-theological look of diaconate in his \\ context in time
}

Luciano Rocha Pinto

\section{Resumo}

A experiência do povo hebreu de um Deus-Pastor, que caminha, protege e conduz às fontes de alimento, adquire visibilidade na concepção cristã do Bom Pastor. As noções de cuidado e de doação atravessam a relação pastorrebanho e ganham sentido a partir da diaconia. A missão da Igreja está atravessada pela exigência do serviço oblativo de si em função do outro. Assim, o objetivo específico deste trabalho é analisar a diaconia da Igreja a partir de um estudo de caso: o diaconado. O Diácono, sacramento do Cristo-Servo, tem seu pastorado, por vezes, reduzido ao assistencialismo e à beneficência, em detrimento de seu caráter missionário e ministerial, restringindo, assim, o real significado de sua diaconia caritatis. A caridade ilumina sua ação pastoral que não está restrita à mera beneficência. Sua ação amorosa tem em vista o bem do rebanho. Rebanho que não é seu, mas de Cristo. Rebanho que não reúne, pois, não é pastor como o sacerdote, mas que pastoreia na comunhão com o Epíscopo e o Presbítero. Seu ministério é, pois, transversal. Seu pastorado relaciona e media altar e assembleia, servindo a Cristo na mesa da Palavra, da Liturgia e da Caridade.

Palavras-chave: Pastorado. Diaconia. Diácono. 


\begin{abstract}
The Hebrew people experience of a God-Shepherd, who walks, protects and leads to food sources, acquires visibility in the Good Shepherd Christian drawing up. Those care and donation ideas cross the shepherd-flock relationship and earns meaning from Diaconia. The Church's mission is crossed by the request of oblative service wich consists in itself serving others. Therefore, the specific objective of this study is to analyze the Church diaconia from a case study: the diaconate. The Deacon, a sacrament by Christ the Servant, has his pasturing, occasionally, reduced to welfare and charitable purposes, in preference of their missionary and ministerial nature, thereby restricting the real meaning of his diaconia caritatis. Charity illuminates his pastoral action that is not restricted to mere beneficence. His loving action is aimed at the good of the flock. A flock that is not his, but Christ's. A flock that does not gathers, since is not a shepherd as the priest, but wich herds in communion with the Episcopo and Presbyter. His ministry is therefore transverse. His pasturing connects and mediates altar and assembly serving Christ in the Word, in the liturgy and charity.
\end{abstract}

Keywords: Pasturing. Diaconia. Deacon.

\title{
Introdução
}

O Senhor, o kyrios, não tirou proveito de sua igualdade com Deus,

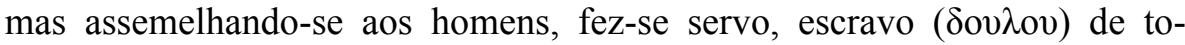
dos (cf. Fl 2,6-8). A exemplo de seu Senhor, "que não veio para ser servido

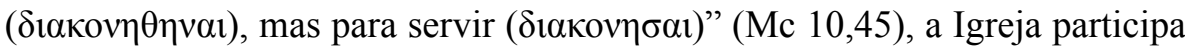
de sua diaconia (cf. Mc 10,43). ${ }^{1}$ Os Apóstolos, de modo particular, são cooperadores de Deus e servidores de Cristo (cf. 1Ts 3,2; 2Cor 6,1). ${ }^{2}$ Estes, por sua vez, transmitiram o encargo que receberam aos Epíscopos e seus colaborados,

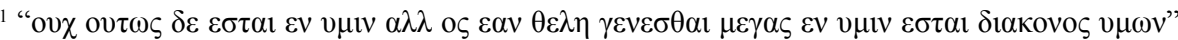
(Mc 10,43).

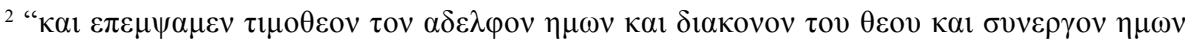

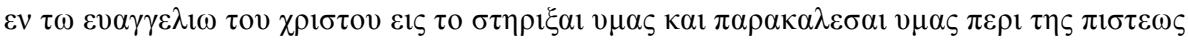

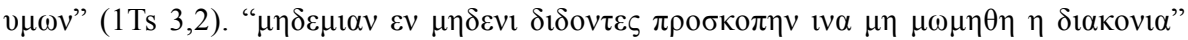
(2Cor 6,3).
} 
os presbíteros e os diáconos, para que, a exemplo de Jesus Cristo, o Bom Pastor, possam pastorear seu redil.

O objetivo deste trabalho é analisar a diaconia da Igreja a partir de um estudo de caso: o diaconado, como ministério permanente. Está dividido em três partes. Na primeira, procuro identificar e descrever a construção da figura do pastor cristão. Tributário do mundo hebreu, o cristianismo faz experiência do sagrado não somente a partir de espaços geograficamente definidos, mas estabelecendo proximidade com um Deus pessoal, que acompanha seu povo e o conduz como um pastor. $\mathrm{O}$ mundo hebreu construiu uma dupla concepção do sagrado: a primeira, que será explorada neste trabalho, emerge da figura de $E l$ Shaddai, o "Deus das estepes" e das montanhas, o "Deus todo poderoso" que "como um pastor, vai apascentar seu rebanho" (Is 40,11); e a segunda, mais tardia, circunscrita a lugares definidos, como o Tabernáculo no deserto, os santuários de Betel, Siloé ou Dã, e, mais tarde, o Templo de Jerusalém. Posteriormente, com a experiência cristã, vemos sua relativização em razão do Novo Templo (cf. At 7). ${ }^{3}$ $\mathrm{Se}$, por exemplo, no mundo grego a divindade restringe-se às cidades, agindo territorialmente, no mundo hebreu Deus retira o povo da cidade para dar-lhe uma nova terra e com ele faz aliança. Jesus radicaliza tal construção. Ele é o Bom Pastor, que dá a vida por suas ovelhas (Jo 10,11).

$\mathrm{Na}$ segunda parte, procuro analisar o pastorado como diaconia caritatis. A diaconia do pastor (Mc 10,45) é um dom compartilhado com toda a Igreja que, servidora e ministerial, tem no diácono o sinal visível e sacramental do Cristo-Servo. Na última parte, apresento um pouco da trama histórica que fez emergir o diaconado, desenvolveu-o e viu seu declínio, a partir dos séculos IV-V e seu restabelecimento no Concílio Vaticano II. Entendo que esse ministério transversal, que atravessa o altar e perpassa a assembleia, deve ser considerado a partir do sentido mais profunda da diaconia de Cristo e da Igreja. Conforme afirma Policarpo de Esmirna (+ 155), os diáconos estão a serviço de Cristo e não de mesas. Logo, pensá-lo simplesmente a partir da ação beneficente significa esvaziar seu ministério.

Assim, as noções de cuidado, zelo, doação e amor fraterno devem iluminar seu tríplice ministério da Liturgia, da Palavra e da Caridade. Seu restabelecimento pelo Vaticano II ocorre precisamente pelo revisitar a diaconia e repensar

\footnotetext{
${ }^{3}$ Cf. CASALEGNO, Alberto. Ler os Atos dos Apóstolos: estudo da teologia lucana da missão. São Paulo: Edições Loyola, 2005, pp. 164-171; EBNER, Martin. "Dos primórdios até a metade do século II”. In: KAUFMANN, Thomas (et al). História Ecumênica da Igreja (1): dos primórdios até a Idade Média. São Paulo: Edições Loyola: Paulus; São Leopoldo, RS: Editora Sinodal, 2012, pp. 15-18.
} 
uma igreja ministerial e servidora. Nesse contexto, foi essencial uma eclesiologia focada na comunidade, Igreja-Povo de Deus, que valorizasse a diversidade dos carismas e concebesse o poder como serviço. O repensar essa Igreja ministerial, atravessada pela diaconia de Cristo, fez emergir o novo diaconado e um novo Diácono que deve ser o sinal privilegiado do Cristo-Servo e Bom pastor.

\section{A construção e os contornos do Pastor: um poder diaconal}

A figura do pastor é emblemática no universo cristão. O próprio Jesus se intitulou o Bom Pastor: "Eu sou o bom Pastor; o bom Pastor dá a sua vida pelas ovelhas" (Jo 10,11). A ideia do pastorado, como ato de zelar e de cuidar, estava presente nas atitudes de Jesus: "E, vendo as multidões, teve grande compaixão delas, porque andavam cansadas e desgarradas, como ovelhas que não têm pastor" (Mt 9,36). Jesus ressuscitado entrega o cuidado de seu rebanho a Pedro: "Simão, filho de Jonas, amas-me? (...) Apascenta as minhas ovelhas" (Jo 21,16). A figura do pastor é, portanto, cara ao cristianismo. Nele encerra-se a noção de serviço, de doação, de cuidado, de condução... propriedades que só existem em relação. O pastor é o mediador entre as ovelhas e a fonte de alimento. A finalidade do ato de pastorear é garantir a vida das ovelhas, alimentando-as e vigiando-as contra os perigos do caminho. Quando Jesus disse a Pedro: "apascenta as minhas ovelhas", ele indicava que Sua missão-serviço era também a de Pedro e, por extensão, dos demais Apóstolos. O pastor cristão é aquele que, fazendo as vezes do Cristo ou, melhor, agindo na pessoa de Cristo, deve ser ponte para o alimento e para a vida. Em última instância, é Cristo que continua agindo e pastoreando. A expressão In persona Christi aponta para esta realidade onde o Cristo, Bom Pastor, continua operando, conduzindo e alimentando, gerando vida, portanto, por meio de seus pastores. Tal condição faz emergir o sagrado na própria pessoa de quem pastoreia. Esta condição não é uma novidade, mas herança do povo hebreu em sua construção do espaço sagrado.

Conforme Mircea Eliade, o espaço não é homogêneo para o homem religioso, mas apresenta roturas, quebras, dando visibilidade a lugares qualitativamente diferentes de outros lugares. "Não te aproximes daqui. Tira as sandálias dos teus pés, porque o lugar em que te encontras é uma terra santa" (Ex 3,5). Esse texto aponta para aquilo que Eliade denomi-

\footnotetext{
${ }^{4}$ ELIADE, Mircea. O sagrado e o profano: a essência das religiões. São Paulo: Martins Fontes, 2001, p. 17.
} 


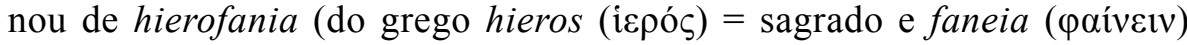
= manifesto) e que pode ser definido como a manifestação/percepção do sagrado. Uma hierofania é o modo pelo qual um lugar emerge não na homogeneidade, mas na singularidade, marcado por uma experiência religiosa. O espaço sagrado, contudo, não deve ser entendido apenas como um lugar geograficamente definido. A experiência do sagrado no mundo grego, é verdade, está caracterizada por esta referência espacial. "O deus grego funda a cidade, indica sua localização, ajuda na construção das muralhas, garante sua solidez, dá seu nome à cidade (...) O deus grego é um deus territorial, um deus intra muros, tem seu lugar privilegiado, seja sua cidade, seja seu templo". ${ }^{5}$ Assim, Atenas tem sobre a cidade de seu nome o dever de proteger e de intervir. A cidade é, em si mesma, uma hierofania, pois manifesta em suas ruas, praças e casas a presença divina. No panteão grego, a relação era territorializada. Contudo, a experiência do sagrado no Oriente mediterrâneo é diferente do mundo grego.

Evidente que há entre os hebreus lugares sagrados: o templo de Jerusalém e, por extensão, sua cidade. Porém, sua experiência primordial com o sagrado não está territorializada. Diferente dos deuses gregos, o Deus hebreu é um Deus que caminha. "Nunca a presença desse Deus hebraico é mais intensa, (...) do que, precisamente, quando seu povo se desloca e quando, na errância do seu povo, em seu deslocamento, nesse movimento que o leva a deixar a cidade, as campinas e os pastos, ele toma a frente de seu povo e mostra a direção que ele deve seguir". ${ }^{6}$ Enquanto o deus grego defende as muralhas da cidade, o Deus hebraico retira seu povo da cidade e o conduz, como um pastor, para fora das muralhas à outra terra. A teologia do povo hebreu se funda num Deus pastor, que se manifesta a uma multiplicidade em movimento. A manifestação do sagrado para o hebreu, que será em grande parte absorvida pelo cristianismo, não está propriamente em um lugar, mas personifica-se no Deus-pastor, que conduz, fala, ensina, alimenta com o maná no deserto e escolhe homens que vão à sua frente e falem por si. Neste sentido, a figura de Moisés é cheia de significado. Michel Foucault analisa um comentário rabínico que reflete muito bem esta questão do pastorado como um poder de cuidado e condução. Nele...

${ }^{5}$ FOUCAULT, Michel. Segurança, território, população: curso dado no Collège de France (1977-1978). Tradução Eduardo Brandão; revisão Claudia Berliner. São Paulo: Martins Fontes, 2008 , p. 168 .

${ }^{6}$ Ibidem. 
...Explica-se como e por que Moisés foi designado por Deus para conduzir o rebanho de Israel. É que quando era pastor no Egito, Moisés sabia perfeitamente fazer suas ovelhas pastarem e sabia, por exemplo, que, quando chegava numa campina, devia mandar primeiro para lá as ovelhas mais jovens, que só poderiam comer a relva mais tenra, depois mandava as ovelhas um pouco mais velhas, e só depois mandava para a campina as ovelhas mais velhas, as mais robustas também, as que poderiam comer a relva mais dura. (...) Era ele que presidia essa distribuição justa, calculada e pensada do alimento, e foi então que Javé, vendo isso, lhe disse: “Já que sabes ter piedade das ovelhas terás piedade do meu povo, e é a ti que eu o confiarei". ${ }^{7}$

O espaço sagrado para o hebreu não está simplesmente determinado geograficamente, mas também é uma hierofania personificada na figura do pastor. Daí a tradição profética que se formou em Israel. O profeta (Pro $=$ antes de, em lugar de, diante de $+P h e m i=$ falar, dizer) é aquele que carrega uma mensagem de Deus e, por isso, fala em Seu nome, em Seu lugar. Ele é, em si mesmo, uma hierofania, pois nele, e por ele, há uma irrupção do sagrado, uma manifestação divina. O cristianismo, tributário do judaísmo, identifica o espaço sagrado não apenas em lugares (templos e cidades), mas, também em indivíduos que, falando em nome de Deus, manifestam sua presença. Na experiência cristã, Jesus não apenas fala em nome de Deus, como é Sua Palavra viva e encarnada (cf. Jo1), Deus feito homem que escolhe outros homens para irem à frente de seu rebanho (cf. Lc 9, 1-2; 10,1; Jo 21,17).

Como Iahweh escolheu Moisés, Jesus escolhe outros homens para serem pastores de seu povo, radicalizando esta relação de reciprocidade: “Quem vos ouve, a mim ouve; e quem vos rejeita, a mim rejeita" (Lc 10,16). Essa experiência é compartilhada no tríplice ministério ordenado. Pela imposição das mãos, os Apóstolos instituíram epíscopos (At 20,28; Fl 1,1; 1 Tm 3,2), presbíteros (At 11,30; 14,23; Tg 5,14; 1Tm 5,17-22) e diáconos (F1 1,1; 1Tm 3,813), como continuadores de seu pastorado. Os textos dos primeiros séculos cristãos apontam para esta realidade onde se reconhece no ministro ordenado a manifestação do sagrado. Inácio de Antioquia (35-107) aconselha "que todos reverenciem os diáconos como Jesus Cristo, tal como também o bispo que é imagem do Pai e os presbíteros como o senado de Deus e como a assembleia

${ }^{7}$ Ibidem, p. 170. 
dos Apóstolos: sem eles não se pode falar de Igreja". ${ }^{8} \mathrm{E}$ ainda: "Segui todos o bispo, tal como Jesus Cristo [segue] o seu Pai, e o presbitério como os Apóstolos; quanto aos diáconos, respeitai-os como à lei de Deus". ${ }^{9} \mathrm{Na}$ "Epístola aos de Filadelfo", coloca os três componentes hierárquicos como sinais de unidade, aconselhando aos fiéis a "permanecerem unidos com o bispo, com os presbíteros e os diáconos". ${ }^{10}$ A Didascalia Apostolorum, composta no princípio do século III, reforça a relação entre o epíscopo e o diácono: "honrareis ao Bispo, como a Deus, porque o Bispo ocupa entre vós o lugar de Deus todo -poderoso. O Diácono tem o lugar de Cristo; assim o amareis". ${ }^{11}$ Estes textos apontam mais que o lugar do corpo ordenado na hierarquia da Igreja. Eles dão visibilidade à manifestação do sagrado que os atravessa. O ordenado é, em si mesmo, uma hierofania.

No entanto, o Pastorado deve ser entendido a partir da diaconia, movimento de ir ao encontro do outro (entendido como cuidado/serviço) e de renunciar a si mesmo. Logo, a exigência de perfeição começa a dar contornos ao seu modo de ser. "Claro, o pastor, na medida do possível, tem de ser perfeito. O exemplo do pastor é fundamental, essencial para a virtude, o mérito e a salvação do rebanho". ${ }^{12}$ São Gregório no Regula Pastoralis, II, 2, afirma: "a mão que limpa o que está sujo nos outros não deve, porventura, ser ela própria limpa e impoluta? Cuidará de ser pura a mão que se dedica a lavar as imundices". Essa exigência de boa conduta já aparece nos textos sagrados cristãos enfatizando o cuidado consigo e com sua família. Assim, a carta de Paulo a Timóteo aponta como devem proceder os bispos e os diáconos: irrepreensíveis, casados uma só vez, sóbrios, prudentes, com regrado proceder, hospitaleiros, capazes de ensinar, não dados à bebida, nem violentos, mas pacíficos e que saibam governar os filhos e a casa (cf. 1Tm 3,2-13). Exige-se do pastor a perfeição do cuidado consigo. Se num primeiro momento o espaço sagrado cristão, tributário do mundo hebreu, diferencia-se do mundo grego,

\footnotetext{
${ }^{8}$ ANTIOQUIA, Inácio de. Carta aos Tarsos 3,1; SCh 10, 113. Disponível em: <http://docslide. com.br/documents/cartas-de-santo-inacio-de-antioquia.html $>$ Acesso em 10 de maio de 2015.

${ }^{9}$ Idem. Carta aos Esmirnenses 8,1; SCh 10, 163. Disponível em: <http://docslide.com.br/documents/cartas-de-santo-inacio-de-antioquia.html $>$ Acesso em 10 de maio de 2015.

${ }^{10}$ Idem. Carta aos Filadélfos, saudação. Disponível em: <http://docslide.com.br/documents/ cartas-de-santo-inacio-de-antioquia.html $>$ Acesso em 10 de maio de 2015.

${ }^{11}$ GIBSON, Margareth Dunlop. The Didascalia Apostolorum in English. Horae Semiticae 1. London: Clay, 1903, n. 26,4-5. Disponível em: <https://archive.org/details/didascaliaaposto00 gibsuoft $>$. Acesso em 10 de maio de 2015.

${ }^{12}$ FOUCAULT, Michel. Segurança, território, população. Op. Cit., pp. 227-228.
} 
com o desenvolvimento do cristianismo ocorrem algumas aproximações que vão incluir novos elementos à figura do pastor. Desde o início da Igreja há contatos com o helenismo. Enquanto os "Doze" compunham o núcleo do grupo de Jesus de língua aramaica, os "Sete", primeiros diáconos, "constituíam a associação diretiva de uma comunidade de língua grega dos que em Atos 6,1 são chamados de helenistas". ${ }^{13}$ Segundo os testemunhos dos Atos dos Apóstolos, após a morte de Estevão ocorre a saída daquele grupo, os dispersos (cf. At 8,4 ), de Jerusalém para fora, em direção ao mundo greco-romano. Sua concepção de espaço sagrado, visível a partir da figura do pastor, parece sofrer influência do que os gregos denominavam "o cuidado de si". A expressão epiméleia heautoû (em latim cura sui) ou o cuidado de si mesmo agrega valor à exigência de vida virtuosa do pastor e do bom governo das almas.

Os dois primeiros séculos da época imperial (séculos I-II) podem ser considerados como a idade de ouro da cultura e do cuidado de si mesmo. ${ }^{14}$ Este modo de governar-se é tema consagrado na antiguidade. Dominar os próprios desejos e impor-se uma rotina não era novidade para a moral grega que via no autodomínio uma virtude. Um conjunto de práticas e técnicas, já existentes no mundo grego, aproximaram-se da figura do pastor num complexo processo de produção subjetiva. Conforme aponta Michel Foucault, "em torno dos cuidados consigo toda uma atividade de palavra e de escrita se desenvolveu, na qual se ligam o trabalho de si para consigo e a comunicação com outrem". ${ }^{15}$ Ou seja, as práticas do cuidado de si não constituíram exercícios solitários, mas práticas sociais que, possivelmente, envolveram os cristãos. ${ }^{16}$ Muito sumariamente, podemos dizer que foram as comunidades neopitagóricas e os grupos epicuristas que institucionalizaram as técnicas e os exercícios de abstinência, exames de consciência, estágios de pobreza e renúncia dos prazeres. Objetivavam fortalecer a alma e buscar o controle de si. ${ }^{17}$ Conforme Paul Veyne, o cristianismo deu uma "justificativa transcendente". ${ }^{18}$ Enquanto

\footnotetext{
${ }^{13}$ KAUFMANN, Thomas; KOTTJE, Raymund; MOELLER, Bernd; WOLF, Hubert. História Ecumênica da Igreja: dos primórdios até a Idade Média. São Paulo: Edições Loyola, Paulus; São Leopoldo, RS: Editora Sinodal, 2012, p. 12.

${ }^{14}$ Cf. FOUCAULT, Michel. História da sexualidade 3: o cuidado de si. Rio de Janeiro: Edições Graal, 1985.

${ }^{15}$ Ibidem, p. 57.

${ }^{16}$ FOUCAULT, Michel. A hermenêutica do sujeito. São Paulo: Martins Fontes, 2004, p. 244.

${ }^{17} \mathrm{Cf}$. Idem. História da sexualidade 3, Op. Cit., pp. 55-71. Idem. Segurança, território, população. Op. Cit., pp. 236-237.

${ }^{18}$ Cf. VEYNE, Paul. "La familie et l'amour sous le haut-empire romain". Annales. Économies,
} 
no mundo antigo era uma busca de si mesmo, com o cristianismo ocorre a renúncia de si, em favor do outro e da salvação.

Eis a primeira característica do pastor cristão: a manifestação do espaço sagrado em seu corpo individual. O ministro ordenado (epíscopo, presbítero e diácono) age na pessoa de Cristo. É sinal de sua presença e instrumento de sua ação. Não um instrumento inerte, mas livre e voluntário. A segunda característica do pastor é a diaconia. "O poder do pastor é um poder que não se exerce sobre um território, é um poder que, por definição, se exerce sobre um rebanho, mais exatamente sobre o rebanho em seu deslocamento". ${ }^{19}$ A diaconia, ou seja, a noção de serviço, de doação, de cuidado... tem por efeito o sacrifício da própria vontade. O pastor deve viver a diaconia do Bom Pastor. "Cristo, claro, é pastor, e é um pastor que se sacrifica para trazer de volta a Deus o rebanho perdido, que chega a se sacrificar não apenas pelo rebanho em geral, mas, por cada uma das ovelhas em particular". ${ }^{20}$ Assim, o pastor deve sacrificar-se pelos outros e, se preciso, dar a vida por suas ovelhas, como Jesus, o Bom Pastor (Jo 10,11). Tributário do mundo hebreu, o cristianismo forja a figura do pastor a partir da noção de serviço. O poder do pastor é, portanto, um poder diaconal.

\section{A diaconia caritatis como expressão do pastorado}

Todas as imagens que Jesus utiliza para si estão atravessadas pela noção de serviço e doação: Ele é o pão (Jo 6,38), a videira (Jo 15,5-6), a luz (Jo 12,46), o pastor (Jo 10,11-12)... ${ }^{21}$ Todas implicam o serviço como chave de compreensão de sua vida e condição de todo aquele que deseja segui-lo: "Desse modo, o Filho do Homem não veio para ser servido, mas para servir e dar a sua vida em resgate de muitos" (Mt 20,28). Por isso, o Verbo feito carne, mesmo sendo de condição divina, esvaziou-se a si mesmo e assumiu a condição de escravo (cf. Fl 2,6-7). Por isso, “....aquele que quiser tornar-se grande entre vós seja aquele que serve" (Mt 20,26). Confiou aos Doze a continuidade de sua missão (cf. Mt 24,14). Podemos afirmar, então, conforme Chamoso, que a Igreja, enquanto continuadora da obra de Cristo, "é por definição ser-

Sociétés, Civilisations 1 (1978), pp. 35-63.

${ }^{19}$ FOUCAULT, Michel. Segurança, território, população. Op. Cit., p. 168.

${ }^{20}$ Ibidem, p. 202.

${ }^{21}$ DURAN, José Duran Y. Diaconato Permanente e Ministério da Caridade. São Paulo: Edições Loyola, 2003, p. 135. 
vidora ou ministerial, missionária a exemplo de Jesus, o servo que 'não veio para ser servido, mas para servir' (Mt 20,28). A diakonía de Jesus ${ }^{22}$ continua na diakonía da Igreja e na diakonía dos ministérios eclesiais". ${ }^{23}$ Assim, o poder pastoral manifesta-se por seu zelo, sua dedicação, sua aplicação constante em tornar-se servo, como o Bom Pastor é Servo. "O mau pastor é aquele que só pensa no pasto para seu próprio lucro (...) O bom pastor só pensa no seu rebanho (...). Creio que vemos surgir aí, esboçar-se aí um poder cujo caráter é essencialmente oblativo e, de certo modo, transicional. (...) O que implica que o poder pastoral, em si, é sempre um bem". ${ }^{24}$

$\mathrm{O}$ pastor exerce um poder oblativo. Voluntariamente disposto à diaconia caritatis, ao serviço gratuito para com o outro. O Bom Pastor é, pois, seu modelo. Enviado pelo Pai, Cristo Jesus envia a Igreja (Jo 20,21). Convoca e envia os Doze (Lc 9,1ss) e o grupo dos Setenta discípulos (Lc 10,1ss). As primeiras comunidades seguiram o exemplo do Senhor. Outros grupos são enviados, como os Sete (At 6,1-6) ${ }^{25}$ e todos que recebem a Palavra de Cristo e a acolhem (Lc 8,15). A natureza da igreja é, portanto, ministerial, pois é sacramento de Cristo Pastor e Servo (cf Mc 10,42-45; 1Cor 4,6-13; 2 Cor 4,5; F1 2,6-11). A Igreja é serva de Cristo no mundo e para o mundo. ${ }^{26}$ "A Igreja é fruto da Missão do Filho e do Espírito Santo enviados pelo Pai. A missão não é, antes de tudo, obra da Igreja, mas ação de Deus". ${ }^{27} \mathrm{O}$ poder pastoral é, pois, um serviço de condução, mediação entre o rebanho e as pastagens. O pastor, a serviço da Igreja, instrumento de Cristo, está marcado pela diaconia. No entanto, toda a igreja é ministerial e está atravessada pela diaconia de Cristo. A raiz da palavra diakón aponta para essa relação na qual alguém age em função e em nome ou sob a autoridade de outro. A um só tempo, indica o ministério apostólico de pregação e designa o encargo de servir e de assistir. Este sentido amplo da

${ }^{22}$ Sobre a diaconia de Cristo e da Igreja, confira: "Da diaconia de Cristo à diaconia dos Apóstolos". In: COMISSÃO TEOLÓGICA INTERNACIONAL. Diaconado: evolução e perspectivas, 2002. Disponível em: $<$ http://www.vatican.va/roman_curia/congregations/cfaith/ cti_documents/rc_con_cfaith_pro_05072004_diaconate_po.html\#_ftn35>. Acesso em 13 de fevereiro de 2016 .

${ }^{23}$ CHAMOSO, R. S. "Los ministérios em perspectiva eclosiologica: el dinamismo ministerial". Seminários 93-94, (1984), p. 404.

${ }^{24}$ FOUCAULT, Michel. Segurança, território, população. Op. Cit., p. 171.

${ }^{25}$ DURAN, José Duran Y. Diaconato Permanente e Ministério da Caridade. Op. Cit., p. 23.

${ }^{26}$ CHAMOSO, R. S. Los ministérios em perspectiva eclosiologica. Op. Cit., p. 372.

${ }^{27} \mathrm{CNBB}$. Missão e ministérios dos cristãos leigos e leigas. Documento 62, n. 44. Disponível em: <http://www.cnbb.org.br/images/arquivos/files_48a047a7b661a.pdf >. Acesso em 5 de fevereiro de 2016. 
diaconia, entendida como obra de amor fraterno-caritativo é próprio de toda a Igreja e ganha visibilidade a partir de práticas diversas de solidariedade, de cuidado e de serviço amoroso.

A Igreja está marcada por esta arte de cuidado, de zelo, de condução e de serviço. "E os poderes que a Igreja detém - como aponta Michel Foucault - são (...) organizados e justificados como poder do pastor em relação ao rebanho". ${ }^{28}$ Os sacramentos, por exemplo, expressam este esmero do pastor para com seu redil. O Batismo agrega a ovelha no aprisco; a Penitencia reintegra a dispersa, enquanto que a Eucaristia é seu alimento. ${ }^{29}$ Práticas diversas nos primeiros séculos apontam para uma ampla diaconia eclesial. Na Didakhe, ${ }^{30}$ datada entre 60 a 100 d.C., lemos: "Não terás as mãos sempre estendidas para receber, retirando-as quando se trata de dar. Se possuíres algo, graças ao trabalho de tuas mãos, dá-o em reparação por teus pecados. Não hesitarás em dar (...) pois, se divides os bens da imortalidade, quanto mais o deves fazer com os corruptíveis". ${ }^{31}$

A Didakhé, um dos documentos mais antigos da catequese cristã, aponta para este espírito fraterno das primeiras comunidades que se estendia em duas frentes: a dos bens da imortalidade e dos bens corruptiveis. Por isso, o livro de Atos dos Apóstolos observa que não "havia entre eles nenhum necessitado, porque todos os que possuíam terras e casas vendiam-nas, e traziam o preço do que tinham vendido e depositavam-no aos pés dos apóstolos. Repartia-se então a cada um deles conforme a sua necessidade" (At 4,34-35). A partilha de bens, certamente, era uma peculiaridade da comunidade cristã. Tertuliano (ca. 160-220) nos conta que os primeiros cristãos levavam tão a sério as palavras do Senhor sobre o amor fraterno ${ }^{32}$ que muitos exclamavam admirados: "Vede como eles se amam!". ${ }^{33}$ Certamente, a comunhão de bens não constituía um

${ }^{28}$ FOUCAULT, Michel. Segurança, território, população. Op. Cit., p. 203.

${ }^{29}$ Ibidem.

${ }^{30}$ Estudiosos estimam que são escritos anteriores a destruição do templo de Jerusalém, entre os anos 60 e 70 d.C. Outros estimam que foi escrito entre os anos 70 e 90 d.C., contudo são coesos quanto a origem sendo na Palestina ou Síria. Denominada, ainda, de "Doutrina dos Doze Apóstolos", trata-se do primeiro catecismo da Igreja. Cf.: RORDORF, W. "Didaché". In: BERARDINO, Angelo di; ANDRADE, Cristina. Dicionário Patrístico e de antiguidades cristãs. Tradução de Cristina Andrade. Petrópolis, RJ: Vozes, 2002, pp. 404-405.

${ }^{31}$ DIDAKHÉ, Capítulo 4, 5-8. Disponível em: <http://www.universocatolico.com.br/index. php?/pdf/didaque.pdf $>$. Acesso em 5 de fevereiro de 2016.

32 "Nisto conhecerão todos que sois meus discípulos: se vos amardes uns aos outros" (Jo 13,35). ${ }^{33}$ TERTULIANO. Apologia, n 39. Disponível em: <http://ibpan.com.br/images/stories/Downloads/Estudos_Biblicos/Tertuliano\%20-\%20Apologia.pdf $>$. Acesso em 7 de fevereiro de 2016. 
ideal desconhecido. Aristóteles (384-322 a.C.) ensinava que as coisas deveriam ser comuns entre os amigos. ${ }^{34} \mathrm{O}$ povo judeu também conhecia o ideal do repartir: "Não deverá haver pobres no meio de ti, porque o Senhor, teu Deus, te abençoará certamente na terra que te dá como posse hereditária" (Dt 15,4). Porém, o que movia as primeiras comunidades cristãs não era um hábito social ou uma necessidade pontual, mas a observância das palavras do Bom Pastor: "Eu vos dei o exemplo para que, assim como eu vos fiz, façais vós também" (Jo 13,15). As primeiras comunidades compreenderam esse legado e caracterizaram-se pela diaconia. ${ }^{35} \mathrm{O}$ cuidado para com o outro não é uma eventualidade, antes, corresponde ao próprio modo de ser Igreja que pode ser vista em práticas cotidianas diversas como, por exemplo, o Ágape.

O ágape constituía em uma refeição comunitária, que tinha por objetivo saciar a fome dos mais empobrecidos. Segundo Hamman, a finalidade diaconal do ágape fica clara quando olhamos para os convidados: pobres, viúvas e outras pessoas assistidas. ${ }^{36}$ Os diáconos exerciam funções específicas. Conforme a Tradição Apostólica de Hipólito de Roma (séc. III), na ausência do presbítero o diácono dava, em casos de urgência, o sinal (signum) aos enfermos com cuidado. Após dar o necessário e receber o que for distribuído, dava graças e, então, comiam. ${ }^{37} \mathrm{~A}$ frequência dos ágapes era, muito possivelmente, diária, celebrados ao entardecer. ${ }^{38}$ Iniciava-se com a presença do bispo. Então, o diácono trazia a lucerna e de pé no meio de todos os fiéis presentes, dava graças e saudava o povo: "O Senhor esteja convosco". O povo respondia: "E com o teu Espírito". Recitava, então, o salmo com o aleluia e todos comiam. Terminada a ceia, de pé, rezavam e os meninos e as virgens entoavam salmos. A seguir, dava-se início à celebração eucarística com o diácono recebendo o cálice do sacrifício. ${ }^{39} \mathrm{O}$ ágape, além de expressão diaconal da Igreja, era uma

${ }^{34}$ Cf. HOEFELMANN, Verner. "A comunhão de bens da comunidade primitiva no contexto da proclamação de Jesus". Palavra Partilhada 1 (1988), p. 24. DRANE, John. A vida da Igreja primitiva: um documentário ilustrado. São Paulo: Paulinas, 1985, p. 77.

${ }^{35}$ RIEFF, Sissi Georg. Diaconia e culto cristão: resgate de uma unidade essencial e suas consequências para a vida das comunidades cristãs. Escola Superior de Teologia (Tese de Doutorado). São Leopoldo, RS, 2003, p. 329.

${ }^{36}$ HAMMAN, A. G. A vida cotidiana dos primeiros cristãos. São Paulo: Paulus, 1997, p. 50.

${ }^{37}$ ROMA, Hipólito de. Tradição Apostólica, 4.3. Disponível em: <http://www.ecclesia.com. br/biblioteca/pais_da_Igreja/tradicao_apostolica_hipolito_roma.html $>$. Acesso em 10 de maio de 2015.

${ }^{38}$ RUHFUS, Martin. Diakonie-Lernen der Gemeinde: Grundzüge einer diakonischen Gemeindepädagogik. Rothenburg: Ernst-Lange-Institut, 1991, p. 36.

${ }^{39}$ ROMA, Hipólito de. Tradição Apostólica, 4.4. Disponível em: <http://www.ecclesia.com. 
prática de denúncia, mesmo que velada, a um sistema que marginalizava, excluía e separava as classes sociais. ${ }^{40}$ Mais tarde, esta prática foi dividida em dois rituais distintos: o culto eucarístico e o ágape não eucarístico, ${ }^{41}$ que parece ter-se tornado diário, enquanto a eucaristia era celebrada pelo Bispo nos finais de semana. Possivelmente, a separação formal se deu por zelo, uma vez que alguns caíram num erro já citado por Paulo entre os Coríntios: a confusão das duas mesas. "Aquele que o come e o bebe sem distinguir o corpo do Senhor, come e bebe a sua própria condenação" (1Cor 11,29).

Todos os fiéis participam da diaconia de Cristo e são corresponsáveis pela missão da Igreja de edificar a humanidade em povo de Deus, Corpo de Cristo e Templo do Espírito Santo. Semelhante ao sacerdócio ministerial dos bispos e padres, que não suprime o sacerdócio comum dos batizados, o ministério diaconal não suprime a diaconia ou o ministério de todo Corpo eclesial. Na qualidade de ministro ordenado, o Diácono foi escolhido, dentre os batizados, para representar sacramentalmente o Cristo-Servo. Deve ser, portanto, a imagem de uma igreja servidora, amorosa e fraterna. ${ }^{42}$ Sua função é a da mediação das diversas diaconias. A igreja, imagem do Bom Pastor, está atravessada pela diaconia de Cristo. Toda ela é diaconal e ministerial. Sua diaconia caritatis não é propriedade de alguns, mas condição de todo Corpo de Cristo, donde o Diácono é sinal visível e sacramental.

\section{A diaconia faz o Diácono: o ministério em sua historicidade}

Todo sujeito é filho de seu tempo. Não é possível tornar-se qualquer sujeito em qualquer época. ${ }^{43}$ Essa constatação não está circunscrita aos indivíduos, mas também aos ministérios. Os padres de hoje, por exemplo, não têm muita coisa a ver com os presbíteros do século II, que não celebravam sozinhos a Eucaristia e não tinham a responsabilidade pastoral de uma comunidade. Naquela igreja pré-nicênica a comunidade era presidida pelo Bispo, que celebrava a eucaristia semanalmente, cercado por seu conselho de presbí-

br/biblioteca/pais_da_igreja/tradicao_apostolica_hipolito_roma.html>. Acesso em 10 de maio de 2015.

${ }^{40}$ RIEFF, Sissi Georg. Diaconia e culto cristão. Op. Cit., p. 51.

${ }^{41}$ Ibidem, p. 48.

${ }^{42}$ BORRAS, Alphonse; POTTIER, Bernard. A graça do diaconato: questões atuais relativas ao diaconato latino. São Paulo: Edições Loyola, 2010, pp. 142-146.

${ }^{43}$ VEYNE, Paul. Foucault: seu pensamento, sua pessoa. Rio de Janeiro: Civilização Brasileira, 2011, p. 179. 
teros e assistido pelos diáconos, seus auxiliares na celebração. ${ }^{44}$ Muita coisa mudou ao longo dos séculos. Os sujeitos são, pois, efeitos daquilo que Foucault batizou como subjetivação, ou seja, não são "naturais" e não preexistem ao seu tempo. Somos efeitos de estetizações que, a cada época moldam-nos por dispositivos diversos, nos quais a liberdade individual confronta-se com outras vontades e forças complexas que forjam a realidade..$^{45} \mathrm{Um}$ olhar sobre o ministério diaconal no tempo pode nos ajudar a compreender melhor o novo diaconado que emergiu com o Concílio Vaticano II.

As primeiras gerações cristãs não nos transmitiram documentação suficiente para formarmos uma imagem primordial do Diácono. Tateamos apontando caminhos de reflexão sobre esse ministério que nasceu da própria exigência da diaconia. A igreja do primeiro século crescia e suas urgências aumentavam. Foi a diaconia que fez o Diácono, ou seja, a necessidade de servir e de estar a serviço do outro está na origem do ministério diaconal. Sua instituição, em Atos 6, é visível mediante alguns sinais importantes, como a reunião da Igreja para sua escolha, a autoridade dos Apóstolos em convocar toda a comunidade e a imposição das mãos (At 6,6), confirmando o caráter sacramental do ofício. Esse gesto liga os Sete à missão dos Doze, a fim de servir a Igreja com a autoridade de Cristo. ${ }^{46}$ Curiosamente, nenhum daqueles diáconos aparece "servindo as mesas", no sentido de uma pastoral da caridade ou ação social. Enviados a servir à semelhança do Cristo-Servo, sua diaconia passa não apenas pelo pão partilhado com o Cristo pobre e sofredor, mas pelo servir o Pão da Palavra de Deus.

Os Atos dos Apóstolos relatam as atividades de Estevão e Felipe. O primeiro realiza milagres em meio ao povo (At 6,8) e prega a Palavra de Deus (At 6, 10; 7, 2-54). Foi o primeiro mártir da Igreja (At 7,55-60), principiando um movimente hostil de perseguição que levará os cristãos para fora de Jerusalém. Os Sete tornam-se, assim, os primeiros perseguidos, mas, também, os primeiros missionários entre os gentios. Pregavam em Antioquia, Fenícia, Chipre, Damasco, Judeia, Cesareia, Jaffa e Gaza. ${ }^{47}$ Felipe funda novas comu-

\footnotetext{
${ }^{44}$ BORRAS, Alphonse; POTTIER, Bernard. A graça do diaconato. Op. Cit., pp. 150-151.

${ }^{45}$ VEYNE, Paul. Foucault. Op. Cit., p. 178.

${ }^{46}$ Cf. AQUINO, João Paulo Thomaz de. “Atos 6,1-7: a gênese do ofício diaconal?”. Fides Reformata 2 (2010), pp. 9-20.

${ }^{47}$ SUFFERT, Georges. Tu és Pedro: santos, papas, profetas, mártires, guerreiros, bandidos. A história dos 20 séculos da Igreja fundada por Jesus Cristo. Rio de Janeiro: Objetiva, 2001, pp. 26-27.
} 
nidades, como Samaria, onde realiza curas e batiza a muitos (At 8, 4-13), em Azoto e em todas as cidades até a Cesareia (At 8,40), onde veio a viver com sua família (At 21,8). O "ide por todo o mundo, pregai o Evangelho a toda criatura" (Mc 16,15) está na base da diaconia da Igreja e o diácono participa dessa missão. Pouco se pode ver naqueles primeiros tempos de uma atuação voltada especificamente para a caridade. Inácio de Antioquia, por volta de 107 d.C., afirma que os diáconos estão a serviço de Cristo e não de mesas, de Deus e não dos homens. ${ }^{48} \mathrm{O}$ pastorado desenvolvido pelos primeiros diáconos correspondia às exigências de uma igreja em expansão. Sua atuação não difere daquela desempenhada pelos Doze. No final do século I aparecem relacionados aos Epíscopos.

A Didakhé coloca o Diácono ao lado do Bispo ao orientar a comunidade na escolha dos pastores: "Escolha bispos e diáconos dignos do Senhor. Eles devem ser homens mansos, desprendidos do dinheiro, verazes e provados, pois também exercem para vocês o ministério dos profetas e dos mestres. Não os despreze porque eles têm a mesma dignidade que os profetas e os mestres". ${ }^{49}$ O Diácono inscreve seu ministério na relação pastoral do bispo com a comunidade..$^{50}$ Em toda tradição patrística, os diáconos são definidos pela sua proximidade com o Epíscopo: são seus olhos e orelhas. Seu pastorado acontece como mediação e transversalidade. Ele não é sacerdote, mas também não é fiel-leigo, antes, à semelhança do Bom Pastor, é o servo de todos. Sua diaconia, ou seja, seu serviço eclesial é o da doação e do cuidado para com o outro. Ele é ordenado ao serviço para viver a diaconia de Cristo. Isso não significa que seu serviço está restrito a uma pastoral da caridade. De modo algum. Conforme Oñatibia, "os diáconos da Igreja primitiva exerciam funções nos três campos clássicos de atividade ministerial: a palavra, a liturgia e a caridade. (...) Nenhuma delas se destaca sobre as outras como para podê-la considerar como função característica dos diáconos". ${ }^{51}$ Julio Bendinelli, em sua tese de doutorado, assevera que "todo estreitamento do conceito de diaconia como sendo basicamente serviço de caridade falseia ou reduz o real alcance do que

\footnotetext{
${ }^{48}$ ANTIOQUIA, Inácio de. Carta aos Tralianos, 2,3. Disponível em: <http://www.atos6.teo.br/ fontes-historicas/inacio-de-antioquia/epistola-aos-tralianos $>$. Acesso em 1 de junho de 2016.

49 DIDAKHÉ, capítulo 15,1-2. Disponível em: <http://www.universocatolico.com.br/index. php?/pdf/didaque.pdf $>$. Acesso em 5 de fevereiro de 2016.

${ }^{50}$ TILLARD, Jean-Marie Roger. "L'Église locale. Ecclésiologie de communion et catholicité". Laval théologique et philosophique 3 (1998), pp. 644-646.

${ }^{51}$ OÑATIBIA, J. "El diaconado em la história de la Iglesia". In: OLIVER ROMAN, Miguel (Ed.). El diaconado de la Iglesia em España. Madrid: Edice, 1987, p. 88.
} 
teria sido o ministério diaconal na Igreja Antiga". ${ }^{52}$ Seria, então, melhor falar de uma caridade pastoral que ganha forma, com o passar do tempo, em duas dimensões distintas e engranzadas de diaconia: a gestão dos bens e o cuidado para com os pobres.

No século I o ofício do diácono está quase que exclusivamente voltado à pregação e ao ensino. No século II, os diáconos aparecem gerenciando a caixa comum a favor dos pobres e dos necessitados. Justino de Roma conta em sua Apologia que os diáconos levavam aos necessitados o alimento espiritual e material, distribuindo a Eucaristia, mas também os bens destinados aos "órfãos e viúvas, aos que por necessidade ou outra causa estão necessitados, aos que estão nas prisões, aos forasteiros de passagem, numa palavra, ele se torna o provedor de todos os que se encontram em necessidade". ${ }^{53}$ A caridade era um ato fraterno de cuidado da alma e do corpo. Pelo sacramento da Ordem os diáconos participam do tríplice múnus do bispo de ensinar, santificar e pastorear. ${ }^{54}$ Conforme aponta a Congregação para o Clero, no Diretório do ministério e da vida dos diáconos permanentes, "o Diácono participa da missão plena do Bispo, realizando sua função não apenas em nome do bispo e com sua autoridade, mas em nome de Cristo e com sua autoridade". ${ }^{55}$ A exemplo do Bom Pastor, o Diácono deve ser o mediador entre as ovelhas e o alimento. No entanto, deve também cuidar das que falecem. O Papa Zeferino (198-217) entregou, por exemplo, ao seu Diácono Calisto a administração dos Cemitérios da Via Ápia, ${ }^{56}$ as catacumbas de São Sebastião e a que posteriormente recebeu o nome daquele Diácono. Os diáconos eram os homens de confiança e os agentes dos bispos. São seus auxiliares no ministério da comunidade, participando, assim, do ministério e da diaconia do Bispo. Muitos, após sua

${ }_{52}$ BENDINELLI, Julio Cesar. Servidor da mesa da Palavra de Deus: estudo teológico-pastoral sobre o ministério do diácono permanente. Rio de Janeiro: Departamento de Teologia/ Programa de Pós-Graduação em Teologia. Pontifícia Universidade Católica do Rio de Janeiro (Tese de doutorado), 2016, p. 168.

${ }^{53}$ ROMA, Justino de. I Apologia, 67,5-6. Disponível em: <http://www.atos6.teo.br/fontes-historicas/justino-de-roma> Acesso em 1 de junho de 2016.

${ }^{54}$ DURAN, José Duran Y. Diaconato Permanente e Ministério da Caridade. Op. Cit., pp. 66 e 87.

${ }^{55}$ CONGREGAÇÃO PARA O CLERO. "Diretório do ministério e da vida dos diáconos permanentes”, n. 22. Disponível em: <http://www.vatican.va/roman_curia/congregations/cclergy/ documents/rc_con_ccatheduc_doc_19980331_directorium-diaconi_po.html $>$. Acesso em 1 de março de $201 \overline{6}$.

${ }^{56}$ WILGES, Irineu. A história e a doutrina do diaconato até o Concílio de Trento. Petrópolis, RJ: Ed. Vozes, 1971, p. 209. 
morte, substituíam-nos no episcopado, como ocorreu com o Diácono São Calisto que, com a morte do Papa Zeferino, foi escolhido pelo clero e pelo povo para substituí-lo.

No campo da beneficência, a atividade do Diácono ganha maior relevo no século III. A Traditio Apostolica aponta que era dever do diácono indicar os doentes da comunidade ao Bispo. Na Didascalia, o diácono aparece como o responsável por atendê-los e acolher os forasteiros. Podemos afirmar que o ministério da caridade ganhou maior significação na pessoa do Diácono. No entanto, sua proximidade com o Bispo fez com que crescessem em poder, assumissem comunidades, mas, principalmente, passassem a administrar os bens eclesiásticos. Houve quem os criticasse! Orígenes $(+254)$ recrimina-os pelo espírito de cobiça. Num texto sobre a expulsão dos vendedores do templo, fala desses "diáconos que não administram bem as mesas do dinheiro da Igreja, mas cometem sempre fraudes a seu respeito". ${ }^{57}$ "Juntam riquezas para si mesmos, desviando o dinheiro dos pobres". ${ }^{58}$ Evidente, que deve haver cautela em naturalizar essas generalizações. É conhecido o conflito de poder entre diáconos e padres dos séculos III e IV. ${ }^{59}$ No século seguinte São Jerônimo também criticou os diáconos romanos. ${ }^{60}$ Seriam todos os diáconos corruptos? Curiosamente, o sínodo de Elvira (ca. 306-309) sublinha o papel preponderante dos diáconos no setor administrativo da Igreja.

No século IV, o diaconado chega a seu auge e dois acontecimentos importantes vão contribuir para seu progressivo desaparecimento: o surgimento dos Arcediáconos e do monacato. O primeiro representava a Ordem dos Diáconos. Era, originalmente, o diácono principal, auxiliar imediato do bispo na administração dos bens da Igreja. Aos poucos sua influência foi crescendo, assumindo cargos muito semelhantes ao atual Vigário-geral ou Vigário-episcopal. ${ }^{61}$ De modo geral, sucediam seus bispos por ocasião da vacância da cá-

${ }^{57}$ ORÍGENES, Comm. in Mat. 16,22; 40,552. In: COMISSÃO TEOLÓGICA INTERNACIONAL. Diaconado: evolução e perspectivas (2002). Disponível em: <http://www.vatican. va/roman_curia/congregations/cfaith/cti_documents/rc_con_cfaith

pro_05072004_diaconate_po.html\#_ftn35>. Acesso em 13 de fevereiro de 2016.

${ }^{58}$ Idem, 16,22; 40,553. Disponível em: <http:/www.vatican.va/roman_curia/congregations/ cfaith/cti_documents/rc_con_cfaith_pro_05072004_diaconate_po.html\#_ftn35>. Acesso em 13 de fevereiro de 2016.

${ }^{59}$ Cf. BORRAS, Alphonse; POTTIER, Bernard. A graça do diaconato. Op. Cit., pp. 47-53.

${ }^{60} \mathrm{Cf}$. PINTO, Luciano Rocha."Diaconado Latino: uma reflexão sobre seu desaparecimento a partir das relações de poder pastoral”. Atualidade Teológica 52 (2016), pp. 106-128.

${ }^{61}$ BRUNETTI, Aury Azelio. Diaconato Permanente: visão histórica e situação atual. São Paulo: 
tedra. Tal conjuntura faz parte de um complexo processo de sacerdotalização que esvaziou de sentido o diaconado. Como este não é o foco central deste trabalho, não vamos nos deter por demais em sua especificidade. Ainda com relação aos bens eclesiásticos, importa apontar que embora a figura do Arcediácono fosse imponente, no século IV, por razões diversas - seja de corrupção, ingerência ou mesmo de relações de poder -, a administração dos bens eclesiais foi, progressivamente, entregue a profissionais. Lembremos que com o Edito de Milão (313 d.C.), no qual o Imperador Constantino declarava o fim das perseguições aos cristãos, ocorre o aumento não apenas de fiéis, mas também dos bens eclesiásticos. "Não se podia deixar a administração de tal patrimônio nas mãos de pessoas pouco preparadas. Essa preocupação já transparece no Concílio de Ancira (314), e o grande Concílio de Calcedônia (451, Cân. 26) estabelece que cada bispo admita um ecônomo". ${ }^{62}$ De modo geral, este homem era ordenado subdiácono.

No campo especificamente da diaconia caritatis a emergência do monacato constituiu outro fator de esvaziamento do diaconado. A disseminação dos mosteiros promoveu o desenvolvimento das localidades e a multiplicação das práticas de caridade. A partir do século IV, ocorre uma constante e progressiva transferência das atividades diaconais de assistência para os monastérios. Isso se deve, por um lado, à atenção constante que os monges destinaram à atividade evangelizadora, fundando escolas, hospitais, abrigos... Posteriormente, as ordens mendicantes também assumiram práticas semelhantes no campo da caridade social. ${ }^{63}$ A partir do século V, principalmente depois das "Diaconias de beneficência", que nasceram no século anterior com a atuação dos monges diaconitas, verifica-se que o diácono não é mais o homem da caridade e nem mesmo, progressivamente, o responsável pelo patrimônio eclesial. O serviço da caridade não é mais diaconal, mas monacal e conventual. A partir do século VII as obras de caridade escapam por completo das mãos dos diáconos. ${ }^{64}$

$\mathrm{Na}$ administração os diáconos ou se tornaram Epíscopos ou foram substituídos por especialistas. Em sua atuação na beneficência foram substituídos pelos monges e frades. Restou-lhes apenas funções litúrgicas, cada vez menos necessárias. Já no final do século V, o Pseudo-Dionísio aponta como o diaconado já não tem qualquer especificidade em relação às outras ordens

Edições Paulinas, 1986, pp. 58-59.

${ }^{62}$ BORRAS, Alphonse; POTTIER, Bernard. A graça do diaconato. Op. Cit., p. 61.

${ }^{63}$ DURAN, José Duran Y. Diaconato Permanente e Ministério da Caridade. Op. Cit., pp. 88-89.

${ }^{64}$ BORRAS, Alphonse; POTTIER, Bernard. A graça do diaconato. Op. Cit., pp. 61-62. 
inferiores ao presbítero. ${ }^{65}$ Concordo com Durán quando afirma que o diaconado na Igreja desaparece quando a diaconia da caridade se transforma em iniciativa de poder ou em problema puramente econômico-administrativo. O diaconado perde seu sentido existencial na medida em que o dinheiro oferecido se tornou apenas capital a ser investido ou bem a ser administrado. ${ }^{66}$ Esta é uma das razões de seu desaparecimento: seu progressivo afastamento da figura do Cristo-Servo e Bom Pastor, pervertendo, assim, o sentido de seu pastorado. A diaconia caritatis é serviço a Cristo e não a homens. É eclesiologia de comunhão e não mero assistencialismo ou exigência administrativa. Quando estes tornaram-se fins e não meios, o diaconado viu-se decadente, pois já não apontava mais o Cristo Bom Pastor nem cumpria sua vocação de mediação.

Seu restabelecimento pelo Concílio Vaticano II ocorre, justamente, no contexto de uma igreja ministerial e servidora, onde o diaconado novo emerge de uma nova eclesiologia (Igreja-Povo de Deus, Comunidade de Fé, esperança e amor, com diversidade de carismas, igualdade, hierarquia como serviço etc), de uma nova teologia dos ministérios (onde toda a Igreja é ministerial e todos são chamados a uma só esperança), de uma concepção de poder como serviço (como uma Igreja "em saída" conforme expressão do Papa Francisco, servidora e diaconal), de uma não absolutização do celibato (que deve ser visto como um carisma, um dom, e não apenas uma disciplina), de um repensar o sacramento da ordem para além do sacerdócio etc. ${ }^{67}$ Toda a igreja é, portanto, ministerial e está atravessada pela diaconia de Cristo: “...aquele que quiser

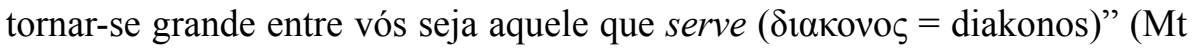
20,26), tendo no Diácono o sinal privilegiado do Cristo-Servo.

A Constituição dogmática sobre a Igreja (Lumen Gentium), em seu número 29, é essencial para pontuarmos a missão e o serviço do diácono. O documento, inicialmente, situa o diaconado como "grau inferior" da hierarquia ("Em grau inferior da hierarquia estão os diáconos"). Esta condição tem por referência o Epíscopo, ao qual está o diácono submetido. Servi-lo é, tradicio-

${ }_{65}$ Pseudo-Dionísio, Hierarquia eclesiastica V, 7; V, 6; PG 3, 506-508. In: COMISSÃO TEOLÓGICA INTERNACIONAL. Diaconado: evolução e perspectivas (2002). Disponível em: $<$ http://www.vatican.va/roman_curia/congregations/cfaith/cti

documents/rc_con_cfaith_pro_05072004_diaconate_po.html\#_ftn35>. Acesso em 13 de fevereiro de 2016.

${ }^{66}$ DURAN, José Duran Y. Diaconato Permanente e Ministério da Caridade. Op. Cit., p. 73.

${ }^{67}$ GOEDERT, Valter Mauricio. O diaconato permanente: perspectivas teológico-pastorais. São Paulo: Paulus, 1995, p. 21. 
nalmente, sua tarefa peculiar. Aliás, sua missão é o serviço, por isso foram ordenados não para o "sacerdócio mas ao ministério". O Concílio aponta, com essa afirmação, mais que a submissão do diácono ao bispo, antes afirma duas condições importantes. A primeira, que ele é a imagem do Cristo-Servo e foi, por isso, ordenado "para o serviço". A segunda, que não foi ordenado "para o sacerdócio", indicando, assim, que o diaconado não é uma etapa para o presbiterado. A natureza de seu ministério, portanto, é o serviço, entendido em relação ao Cristo-Servo, o Bom Pastor. Seu dinamismo é da comunhão eclesial, da mediação e da relação, atuando no ministério da liturgia, da Palavra e da caridade. ${ }^{68}$

\section{Considerações finais}

"Não há necessidade teológica ou pastoral para denegar ou deixar de reconhecer, em relação ao diácono, uma atuação in persona Christi servi. Também ele, como ministro ordenado, age sacramentalmente na pessoa de Cristo, o Cristo servidor" ${ }^{69} \mathrm{O}$ diácono ativa um espaço sagrado caracterizado pela mediação. O novo diaconado é ponte, relação, envolvimento. Sua caridade não se reduz à beneficência. Ele não se isola nas obras de assistência, pois atuando na pessoa de Cristo, Bom Pastor, todos seus gestos e palavras devem ser fonte de amor fraterno. $\mathrm{O}$ foco do diácono é sua missão: o bem do rebanho. Rebanho que não é seu, mas de Cristo. Rebanho que não reúne, pois não é pastor como o sacerdote, mas que pastoreia na comunhão. Sua presença na comunidade atravessa a assembleia e o altar. Relaciona-os, media-os. Seu ministério é, pois, transversal. Seu lugar hierárquico é o do serviço e seu pastorado constitui o ato de conduzir e zelar pelo rebanho, alimentando-o com o Pão da Palavra (pregando, orientando, ensinando, aconselhando), com o Pão eucarístico (auxiliando os sacerdotes na liturgia e levando o viático aos enfermos), e com o pão da caridade fraterna (visitando os doentes e edificando o bem pelas múltiplas formas de caridade). "Em tudo a caridade", conforme dizia Santo Agostinho.

O ministério diaconal remete, a todo instante, a consciência e a prática da Igreja a seu essencial: o serviço. Ele é icona vivens Christi servi in Ecclesia. Seu ministério é da proximidade e da comunhão fraterna. Seu compro-

${ }^{68}$ PETROLINO, Enzo. Diaconado: Serviço-Missão. Do Concílio Vaticano II a João Paulo II. São Paulo: Paulus, 2007, pp. 34-37.

${ }^{69}$ BENDINELLI, Julio Cesar. Servidor da mesa da Palavra de Deus. Op. Cit., p. 104. 
misso é o do serviço. Para isso foi ordenado: para servir a Cristo no outro. Seu poder pastoral é o do cuidado e da doação de si em favor da salvação. Como bem disse Paulo VI, "para apascentar o Povo de Deus (...) Cristo Senhor instituiu na Igreja diversos ministérios (...) Entre esses ministérios, já desde o tempo dos Apóstolos, salienta-se e aparece com particular relevo o diaconado o qual foi tido sempre em grande estima na Igreja". ${ }^{70}$ Certamente, a razão para isso se deve ao dom inefável da diaconia que perpassa todo o Corpo de Cristo e se personifica no Diácono, sacramento de Cristo-Servo e Bom Pastor.

\section{Referências bibliográficas}

ANTIOQUIA, Inácio de. Carta aos Tarsos. Disponível em: <http://docslide. com.br/documents/cartas-de-santo-inacio-de-antioquia.html>. Acesso em 10 de maio de 2015.

ANTIOQUIA, Inácio de. Carta aos Esmirnenses. Disponível em: <http:// docslide.com.br/documents/cartas-de-santo-inacio-de-antioquia.html $>$. Acesso em 10 de maio de 2015.

ANTIOQUIA, Inácio de. Carta aos Filadélfos. Disponível em: <http:// docslide.com.br/documents/cartas-de-santo-inacio-de-antioquia.html $>$. Acesso em 10 de maio de 2015.

ANTIOQUIA, Inácio de. Carta aos Tralianos, 2,3. Disponível em: <http:// www.atos6.teo.br/fontes-historicas/inacio-de-antioquia/epistola-aostralianos>. Acesso em 1 de junho de 2016.

AQUINO, João Paulo Thomaz de. “Atos 6,1-7: a gênese do ofício diaconal?”. Fides Reformata (2010), pp. 9-20.

BENDINELLI, Julio Cesar. Servidor da mesa da Palavra de Deus: estudo teológico-pastoral sobre o ministério do diácono permanente. Rio de Janeiro: Departamento de Teologia/Programa de Pós-Graduação em Teologia. Pontifícia Universidade Católica do Rio de Janeiro (Tese de doutorado), 2016.

\footnotetext{
${ }^{70}$ PAULO VI, Papa. "Constituição Apostólica Ad Pascendum”, 1972, §§ 1 e 2. Disponível em: $<$ http://w2.vatican.va/content/

paul-vi/pt/motu_proprio/documents/hf_p-vi_motu-proprio_19720815_ad-pascendum.html>. Acesso em 13 de fevereiro de 2016.
} 
BORRAS, Alphonse; POTTIER, Bernard. A graça do diaconato: questões atuais relativas ao diaconato latino. São Paulo: Edições Loyola, 2010.

BRUNETTI, Aury Azelio. Diaconato Permanente: visão histórica e situação atual. São Paulo: Edições Paulinas, 1986.

CASALEGNO, Alberto. Ler os Atos dos Apóstolos: estudo da teologia lucana da missão. São Paulo: Edições Loyola, 2005.

COMISSÃO TEOLÓGICA INTERNACIONAL. "Diaconado: evolução e perspectivas" (2002). Disponível em: <http://www.vatican.va/roman_ curia/congregations/cfaith/cti_documents/rc_con_cfaith_pro_05072004_ diaconate_po.html\#_ftn35>. Acesso em 13 de fevereiro de 2016.

CONGREGAÇÃO PARA O CLERO. "Diretório do ministério e da vida dos diáconos permanentes". Disponível em: <http://www.vatican.va/ roman_curia/congregations/cclergy/documents/rc_con_ccatheduc doc_19980331_directorium-diaconi_po.html $>$. Acesso em 1 de março de 2016.

CHAMOSO, R. S. "Los ministérios em perspectiva eclosiologica: el dinamismo ministerial”. Seminários 93-94 (1984), pp. 367-425.

CNBB. Missão e ministérios dos cristãos leigos e leigas. Documento 62. Disponível em: <http://www.cnbb.org.br/images/arquivos/ files_48a047a7b661a.pdf $>$. Acesso em 5 de fevereiro de 2016.

BERARDINO, Angelo di; ANDRADE, Cristina. Dicionário Patrístico e de antiguidades cristãs. Tradução de Cristina Andrade. Petrópolis, RJ: Vozes, 2002.

DIDAKHÉ. Disponível em: <http://www.universocatolico.com.br/index. php?/pdf/didaque.pdf $>$. Acesso em 5 de fevereiro de 2016.

DRANE, John. A vida da Igreja primitiva: um documentário ilustrado. São Paulo: Paulinas, 1985.

DURAN, José Duran Y. Diaconato Permanente e Ministério da Caridade. São Paulo: Edições Loyola, 2003.

EBNER, Martin. "Dos primórdios até a metade do século II". In: KAUFMANN, Thomas (et al). História Ecumênica da Igreja (1): dos primórdios até a Idade Média. São Paulo: Edições Loyola: Paulus; São Leopoldo, RS: Editora Sinodal, 2012. 
ELIADE, Mircea. O sagrado e o profano: a essência das religiões. São Paulo: Martins Fontes, 2001.

FOUCAULT, Michel. Segurança, território, população: curso dado no Collège de France (1977-1978). Tradução Eduardo Brandão; revisão Claudia Berliner. São Paulo: Martins Fontes, 2008.

FOUCAULT, Michel. A hermenêutica do sujeito. São Paulo: Martins Fontes, 2004.

FOUCAULT, Michel. História da sexualidade 3: o cuidado de si. Rio de Janeiro: Edições Graal, 1985.

GOEDERT, Valter Mauricio. O diaconato permanente: perspectivas teológicopastorais. São Paulo: Paulus, 1995.

GIBSON, Margareth Dunlop. The Didascalia Apostolorum in English. Horae Semiticae 1. London: Clay, 1903. Disponível em: <https://archive.org/ details/didascaliaaposto00gibsuoft>. Acesso em 10 de maio de 2015.

HAMMAN, A. G. A vida cotidiana dos primeiros cristãos. São Paulo: Paulus, 1997.

HOEFELMANN, Verner. "A comunhão de bens da comunidade primitiva no contexto da proclamação de Jesus". Palavra Partilhada 1 (1988), pp. 20-28.

KAUFMANN, Thomas; KOTTJE, Raymund; MOELLER, Bernd; WOLF, Hubert. História Ecumênica da Igreja: dos primórdios até a Idade Média. São Paulo: Edições Loyola: Paulus; São Leopoldo, RS: Editora Sinodal, 2012.

OÑATIBIA, J. "El diaconado em la história de la Iglesia”. In: OLIVER ROMAN, Miguel (Ed.). El diaconado de la Iglesia em España. Madrid: Edice, 1987.

PAULO VI, Papa. "Constituição Apostólica Ad Pascendum" 1972. Disponível em: <http://w2.vatican.va/content/paul-vi/pt/motu_proprio/documents/ hf_p-vi_motu-proprio_19720815_ad-pascendum.html>. Acesso em Acesso em 13 de fevereiro de 2016.

PETROLINO, Enzo. Diaconado: Serviço-Missão. Do Concílio Vaticano II a João Paulo II. São Paulo: Paulus, 2007.

PINTO, Luciano Rocha. "Diaconado Latino: uma reflexão sobre seu 
desaparecimento a partir das relações de poder pastoral". Atualidade Teológica 52 (2016), pp. 106-128.

RIEFF, Sissi Georg. Diaconia e culto cristão: resgate de uma unidade essencial e suas consequências para a vida das comunidades cristãs. Escola Superior de Teologia (Tese de Doutorado). São Leopoldo, RS, 2003.

ROMA, Hipólito de. "Tradição Apostólica". Disponível em: <http://www. ecclesia.com.br/biblioteca/pais_da_Igreja/tradicao_apostolica_hipolito_ roma.html>. Acesso em 10 de maio de 2015.

ROMA, Justino de. I Apologia. Disponível em: $<$ http://www.atos6.teo.br/fonteshistoricas/justino-de-roma>. Acesso em 1 de junho de 2016.

RORDORF, W. "Didaché". In: BERARDINO, Angelo di; ANDRADE, Cristina. Dicionário Patrístico e de antiguidades cristãs. Tradução de Cristina Andrade. Petrópolis, RJ: Vozes, 2002.

RUHFUS, Martin. Diakonie-Lernen der Gemeinde: Grundzüge einer diakonischen Gemeindepädagogik. Rothenburg: Ernst-Lange-Institut, 1991.

SUFFERT, Georges. Tu és Pedro: santos, papas, profetas, mártires, guerreiros, bandidos. A história dos 20 séculos da Igreja fundada por Jesus Cristo. Rio de Janeiro: Objetiva, 2001.

TERTULIANO. Apologia. Disponível em: <http://ibpan.com.br/images/ stories/Downloads/Estudos_Biblicos/Tertuliano\%20-\%20Apologia.pdf $>$. Acesso em 7 de fevereiro de 2016.

TILLARD, Jean-Marie Roger. “L'Église locale. Ecclésiologie de communion et catholicité". Laval théologique et philosophique 3 (1998), pp. 644646.

VEYNE, Paul. Foucault: seu pensamento, sua pessoa. Rio de Janeiro: Civilização Brasileira, 2011.

VEYNE, Paul. "La familie et l'amour sous le haut-empire romain". Annales. Économies, Sociétés, Civilisations 1 (1978), pp. 35-63.

WILGES, Irineu. A história e a doutrina do diaconato até o Concílio de Trento. Petrópolis, RJ: Ed. Vozes, 1971. 


\section{Luciano Rocha Pinto}

Doutor em História - Universidade do Estado do Rio de Janeiro Pós-doutorando em Teologia - Pontifícia Universidade Católica do Rio de Janeiro Rio de Janeiro / RJ - Brasil E-mail: luciannrorocha@msn.com

Recebido em: 17/07/16 Aprovado em: 21/11/16 